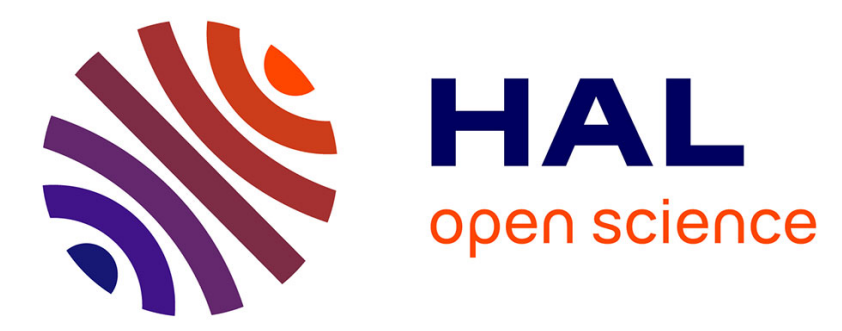

\title{
Tsunamigenic potential due to frontal rupturing in the Sumatra locked zone
}

Alvina K. Kuncoro, Nadaya Cubas, Satish C. C. Singh, Marie Etchebes, Paul Tapponnier

\section{- To cite this version:}

Alvina K. Kuncoro, Nadaya Cubas, Satish C. C. Singh, Marie Etchebes, Paul Tapponnier. Tsunamigenic potential due to frontal rupturing in the Sumatra locked zone. Earth and Planetary Science Letters, 2015, 432, pp.311-322. 10.1016/j.epsl.2015.10.007 . hal-01231612

\section{HAL Id: hal-01231612 \\ https://hal.science/hal-01231612}

Submitted on 1 Dec 2015

HAL is a multi-disciplinary open access archive for the deposit and dissemination of scientific research documents, whether they are published or not. The documents may come from teaching and research institutions in France or abroad, or from public or private research centers.
L'archive ouverte pluridisciplinaire HAL, est destinée au dépôt et à la diffusion de documents scientifiques de niveau recherche, publiés ou non, émanant des établissements d'enseignement et de recherche français ou étrangers, des laboratoires publics ou privés. 


\title{
Tsunamigenic potential due to frontal rupturing in the Sumatra locked zone
}

\author{
Alvina Kusumadewi Kuncoro ${ }^{a}$, Nadaya Cubas ${ }^{a^{*}}$, Satish C. Singh ${ }^{a}$, Marie Etchebes ${ }^{b}$, Paul \\ Tapponnier ${ }^{\mathrm{b}}$ \\ ${ }^{\text {a }}$ Laboratoire Géosciences Marines, Institut de Physique du Globe (CNRS, Paris Diderot, Sorbonne Paris Cité), 1 rue \\ Jussieu, 75238 Paris Cedex 05, France \\ ${ }^{\mathrm{b}}$ Tectonics Research Group, Earth Observatory of Singapore, Nanyang Technological University, N2-01A-10B, 50 \\ Nanyang Avenue, Singapore 639798 \\ * Corresponding author, now at Institut des Sciences de la Terre, Université Pierre et Marie Curie, UMR 7193, 4 \\ place Jussieu 75005 Paris, France.nadaya.cubas@upmc.fr
}

Abstract

The Sumatra subduction zone is one of the most seismically active subduction zones. Although there have been three $\mathrm{Mw} \geq 8.4$ earthquakes in the region, including the disastrous $2004 \mathrm{Mw}=9.2$ Sumatra-Andaman earthquake, a $500 \mathrm{~km}$ long patch around Mentawai Islands is still locked and could produce a large megathrust earthquake. If the rupture propagates to the subduction front, as it most likely occurred during the 2004 earthquake, it may lead to a devastating tsunami. Here, we present high-resolution reflection seismic data from the Sumatra locked zone that shows the subduction interface down to $20 \mathrm{~km}$ depth. The seismic data also show that the wedge is composed of two layers: a shallow layer formed by mixed to landward vergent thrusts, termed as 
pop-ups, and a deeper layer showing sub-horizontal reflectors. The lower layer is most probably formed by duplexes, whose roof serves as a pseudo-décollement for the mixed to landward thrust systems. Based on the seismic results, we perform mechanical modeling in order to understand the formation of these structures and to retrieve the associated frictional properties. We first show that the activation of the pseudo-décollement requires (1) either a sudden increase of effective friction along the plate interface or an irregular geometry of the plate interface, (2) a lower effective friction along the pseudo-décollement than along the plate interface. We then show that low effective frictional values $(\leq 0.1)$ are required to reproduce the observed frontal structures. The low effective friction along the pseudo-décollement could either be due to the presence of a long-term high pore pressure layer or to dynamic weakening associated with earthquakes. Since similar structures are present in the 2010 tsunami earthquake area, we favor the dynamic weakening hypothesis. According to the mechanical modeling, if the next rupture propagates up to the toe rupturing the three most frontal pop-up structures, we could expect at least 5.5 to $9.2 \mathrm{~m}$ of frontal horizontal displacement and a frontal uplift of 2 to $6.6 \mathrm{~m}$ along the frontal thrusts. This would amplify the uplift of the water column and, as a consequence, generate a large tsunami.

Keywords: Sumatra subduction zone; Mentawai seismic gap; Tsunami assessment; Frontal rupturing; Frictional properties.

\section{Introduction}

The Sumatra subduction zone is known as one of the most seismically active zones in the world, where the Indo-Australian plate subducts beneath the Sunda plate at a $10^{\circ}$ azimuth 
leading to an increasing obliquity towards the north and a decrease of the convergence rate from $60 \mathrm{~mm} / \mathrm{yr}$ near the southern Sumatra to $52 \mathrm{~mm} / \mathrm{yr}$ in the northern Sumatra (Prawirodirdjo et al., 2000) (Fig. 1a). This obliquity leads to a slip partitioning into a pure thrust motion along the plate interface and a strike-slip motion along the Great Sumatra Fault, which traverses the continental block of the main land Sumatra (McCaffrey, 1992). It has been suggested that a part of the strike-slip motion is also accommodated along a strike-slip fault system (West Andaman Fault and Mentawai Fault) (e.g. Martin et al., 2013) between the trench and the Great Sumatra Fault, but deep seismic reflection data indicate that these fault systems are dominantly backthrusts (Singh et al., 2011b; Mukti et al, 2012; Singh et al., 2013).

During the last decade, the Sumatra subduction zone has experienced the most intense sequence of earthquakes ever recorded (Fig. 1a). The sequence started with the third largest recorded event, the $\mathrm{Mw} \sim 9.2$ Sumatra-Andaman earthquake of December, 26th 2004 that ruptured over $1300 \mathrm{~km}$ of the subduction zone propagating from northwest Simeulue Island to northern Andaman Island (Lay et al., 2004; Ammon et al., 2005; Singh et al., 2008). The earthquake generated a devastating tsunami with run-up height up to $30 \mathrm{~m}$ (Geist et al., 2006) causing enormous causalities. This event was followed by the $\mathrm{Mw}=8.7$ Nias earthquake in March, 2005, which ruptured a $350 \mathrm{~km}$ long patch located south of the 2004 rupture producing only a minor tsunami (Hsu et al., 2006). The sequence resumed in 2007 along the southern Mentawai area with two successive major earthquakes within a range of twelve hours. The first one, the $\mathrm{Mw}=8.4$ event, ruptured a patch located beneath the southern Mentawai islands while the second one with $\mathrm{Mw}=7.9$ occurred beneath the forearc basin at $\sim 40 \mathrm{~km}$ depth (Konca et al., 2008). The last big event, presumably a consequence of the previous twin earthquakes, occurred in 2010 and ruptured the up-dip portion of the Mentawai earthquakes region of 2007 with a 
magnitude of 7.8 (Singh et al., 2011a). This event, qualified as a tsunami earthquake, characterized by moderate shaking but a large tsunami (Kanamori, 1972), generated tsunami run ups up to $9 \mathrm{~m}$ on Pagai Island (Lay et al., 2011; Hill et al., 2012).

Coupling models obtained from geodetic and paleogeodetic data for interseismic strain estimates show a heterogeneous coupling along the Sumatra subduction zone (Chlieh et al., 2008; Konca et al., 2008) (Fig. 1b). Two main areas appear to be highly locked: the first one is located in the 1805 earthquake, which ruptured completely during the $2005 \mathrm{Mw}=8.7 \mathrm{Nias}$ earthquake, and the second is located beneath the Mentawai islands in the area of the historical earthquakes rupture zones of the $1797 \mathrm{Mw} \sim 8.7-8.9$ and the $1833 \mathrm{Mw} \sim 8.9-9.1$. The 2007 and 2010 events only ruptured parts of the southern area of the second locked segment, leaving a 500 $\mathrm{km}$ long northern Mentawai segment still fully locked. According to geodetic and paleogeodetic measurements, the recurrence time of those Mentawai earthquakes is of 250 yrs (Natawidjaja et al., 2006; Sieh et al., 2008). The northern Mentawai segment is thus ready for a new rupture and a slip deficit of 8 to $10 \mathrm{~m}$ has been accumulated since the 1797 and 1833 earthquakes (Chlieh et al., 2008). From historical records, we also know that the 1797 earthquake produced a devastating tsunami in Padang area with a run-up height of more than $10 \mathrm{~m}$. The northern Mentawai segment might produce again a great earthquake, and possibly a tsunami, which could be devastating for the coastal region of central and southern Sumatra. Therefore, it is important to assess the earthquake and tsunami risk in this region.

Since frontal sections of megathrust are composed of unconsolidated sediments characterized by a rate-strengthening behavior (Byrne et al., 1992; Oleskevich et al., 1999; Scholz, 1998), they were supposed to slip aseismically. However, the $2011 \mathrm{Mw} 9.0$ Tohoku-Oki earthquake has challenged this classical view. The earthquake produced exceptionally large 
shallow slip generating a major tsunami (Bletery et al., 2014; Ide et al., 2011; Ozawa et al., 2011). The rupture propagated all the way to the trench, with the shallow-portion displacement of 15 to $40 \mathrm{~m}$ as attested from the displacement of ocean-bottom pressure gages (Ito et al., 2011) and comparison of bathymetric profiles measured in 1999 and after the earthquake in March 2011 (Fujiwara et al., 2011). Up-dip rupture has also been suggested for the 2004 SumatraAndaman earthquake from co-seismic models (Ishii et al., 2005; Ammon et al., 2005; Chlieh et al., 2006), and from the aftershock pattern (Tilman et al., 2010).

Assessing the potential for frontal rupturing of a megathrust earthquake remains difficult because of the very poor sensitivity near the trench of geodetic model based on inland GPS stations (Loveless and Meade, 2011; Hill et al., 2012). One way to overcome this problem is to study the accretionary wedge structure to determine if the deformation might have been acquired during co-seismic slip. For instance, based on mechanical modeling of deformation, Cubas et al. (2013b) find two regimes of deformation along the Tohoku-Oki accretionary prism: one producing thrusts faults in the frontal region, most probably during the interseismic period, and the other leading to the activation of a landward normal fault due to a strong dynamic weakening during frontal rupturing. Structural analysis of seismic surveys located in the area of the 2004 Sumatra-Andaman led several authors to suggest that the earthquake propagated up-dip (Fisher et al., 2007; Mosher et al., 2008; Dean et al., 2008; Gulick et al., 2011), and may have used thrust faults of the prism (Henstock et al., 2006) or of the oceanic crust (Singh et al., 2008) to break the surface, enhancing the uplift of the water column and as a consequence the tsunami. Active faults near the subduction front have also been observed in the 2010 earthquake rupture zone in the southern Mentawai segment (Singh et al., 2011a). 
In this paper, we assess the possibility of frontal rupturing in the Mentawai locked zone using seismic reflection data located in the gap region (Fig. 1) and performing the mechanical modeling. We propose to discuss the mode of deformation, either seismic or aseismic, of the frontal structures from the deduced mechanical parameters. We will then discuss the seismic and tsunami risks in the region.

\section{Data Acquisition and Processing}

This study is based on a $220 \mathrm{~km}$ long seismic reflection profile acquired by CGG, a seismic company, in 2009 (Fig. 1 and 2). The profile CGGV10 traverses the Sumatra locked zone orthogonal to the trench and is located between Siberut and Sipora Islands. The marine vessel Geowave Champion towed 3 streamers: one 15-km long streamer, the longest ever used, deployed at $22.5 \mathrm{~m}$ water depth to get very deep structures and two 6-km long streamers deployed at $15 \mathrm{~m}$ and $7.5 \mathrm{~m}$ to image sedimentary strata. A seismic source with an array of 48 air guns was deployed at $15 \mathrm{~m}$ and the shot interval was $50 \mathrm{~m}$. The receiver group interval was 12.5 $\mathrm{m}$ and the record length was $20 \mathrm{~s}$. The data from the three streamers were combined to obtain a broadband seismic response (Singh et al., 1996). The multiples were the main problem for seismic imaging that was removed using a combination of Radon multiple removal, surfacerelated multiple removal and diffraction multiple techniques. After iterative velocity analyses, the data were migrated using Kirchoff prestack depth migration (Singh et al., 2011b).

In Figure 2, we show $\sim 120 \mathrm{~km}$ of the profile that covers a part of the subducting oceanic crust, the trench, and up to $100 \mathrm{~km}$ of the accretionary wedge. Both smoothed interval velocity and seismic reflection images are shown. The presence of deeper reflections from the subducting 
plate and the long streamer $(15 \mathrm{~km})$ provides good constraints on the root mean square (RMS) velocity down to $8-10 \mathrm{~km}$ depth. The interval velocity was obtained from the RMS velocity using the Dix equation and was smoothed using a robust local regression (Fig. 2b). The combined velocity and seismic image is shown in Figure 2c.

\section{Seismic data interpretation}

\subsection{Incoming Plate Structure}

The water depth at the seafloor near the trench is about $5 \mathrm{~km}$. On the southwest of the profile at the distance between -16 and $-7.5 \mathrm{~km}$, we can observe a bathymetric high that is a part of the Investigator Ridge (Fig. 2). On the northeastern side of the ridge, the oceanic sediment thickness increases from 0 to $1.2 \mathrm{~km}$ towards the trench (Fig. 2a and 3). Two structures along the oceanic crust are imaged, one at the trench and the second $22 \mathrm{~km}$ landward (fig. 3). They could either correspond to old normal faults or bathymetric features associated with the subducting Investigator fracture zone, although the geometry of these structures is more consistent with normal faults. The first normal fault (NF1) seems to have recently been re-activated as a thrust. The re-activation of the second topographic feature (NF2 or Ridge) is difficult to decipher as it lies beneath $5 \mathrm{~km}$ of deformed sediments, it also likely has been re-activated as a thrust fault, cutting though the oceanic crust. Similar normal faults re-activated as thrust faults have been observed on the 2010 earthquake rupture zone (Singh et al., 2011). The top of the oceanic plate can be imaged up to $80 \mathrm{~km}$ distance from the trench and beyond.

\subsection{Accretionary wedge}


The image of the top of the oceanic crust allows us to estimate thickness of accretionary wedge sediments and dip of the subducting plate. The thickness of sediments in the accretionary wedge increases from $1.5 \mathrm{~km}$ at the deformation front to $>15 \mathrm{~km}$ at the northeast end of the profile. The superimposition of the seismic profile with the interval velocity model highlights a discontinuity within the sedimentary layer in the accretionary wedge (Fig. 2c). This discontinuity is almost horizontal and separates a layer of low velocity $(<2 \mathrm{~km} / \mathrm{s})$ with pop-up structures above from a higher velocity layer $(4-5 \mathrm{~km} / \mathrm{s})$ with mostly horizontal reflectors. This discontinuity could be due to a transition in amount of sediment compaction (Ghosal et al., 2014). The upper layer thickness varies from $2 \mathrm{~km}$ at the trench to $4 \mathrm{~km}$ landward and is formed by series of pop-up structures and landward thrusts-apparently rooting at the above discontinuity (Fig. 3 and 4). Since our study addresses the problem of frontal rupturing, we will now focus mainly on the $37 \mathrm{~km}$-long frontal section of the profile (Fig. 3).

\subsection{Pop-up structures}

A pop-up is a section of hanging-wall strata that has been uplifted by the combination of a seaward vergent thrust and a landward vergent thrust (McClay, 1992). As shown on figures 3b

and 4, the amount of throw on the landward vergent limb is often larger than on the seaward vergent thrust. The margin is thus composed of mixed to landward vergent thrust systems. A total of 11 thrust systems are observed along the frontal section of the profile, which can be divided into 3 to 4 units.

The first unit is composed of three pop-ups over the first $6 \mathrm{~km}$ of the profile from the trench (T1, T2, T3, Fig. 3 and 4). The vergence of the third structure is clearly landward, 
whereas the first and second pop-ups are mixed vergent thrusts. These three structures seem to be connected to each other along an intermediate layer in the wedge (ID1) that connects farther northeastward to the plate interface by most likely a ramp (R1, Fig. 3 and 4).

Another pop-up is located at $1 \mathrm{~km}$ from the first unit (T4, Fig.3), which connects directly to the subduction interface through a ramp (R2). This feature is followed by a landward vergent thrust (T5) at $\sim 10 \mathrm{~km}$ from the trench. This thrust is also located above the plate interface and seems to be connected to the plate interface by another ramp (R3).

The next unit at $12.5 \mathrm{~km}$ from the trench is formed by three structures, two mixed to landward vergent thrusts (T6, T7) and one large landward vergent thrust (T8), rooting along an intermediate layer (ID2) that connects to the plate interface by ramps R5 and R6. The fifth ramp (R5a and R5b) seems to be linked to an oceanic crustal feature, most likely an old normal fault or a ridge as discussed above (NF2 or Ridge). The NF2 feature might be somehow accommodated by additional duplexing between R5 and R6, which implies a complexity in the décollement in this region as well.

The last unit is again composed of three pop-ups, two mixed vergent (T9, T10) and one large landward vergent thrust (T11), connected to the intermediate layer (ID3) by the supposed ramp R7.

\subsection{Pseudo-décollement and duplexes}

All pop-ups root into an intermediate layer. This intermediate layer could either be a décollement or the roof of duplexes formed by ramps coming from the plate interface and 
located in the deep layer. The roof of those duplexes will then act as a pseudo-décollement leading to the formation of the shallow pop-ups. This intermediate layer has a positive slope, and we do not see a major structure connecting a unique décollement to the plate interface farther northeastward. In addition, we do see some markers of potential ramps in the deep layer (Fig. 4). We thus chose to call this layer a pseudo-décollement, which divides the pop-up structures above from the duplexes below. The interval velocity model, although poorly constrained, (Fig. 2b, c), suggests a change in velocity where this pseudo-décollement is located, which could be due to the transition in amount of sediment compaction. Duplexes would then be 1 to $3 \mathrm{~km}$ thick, spaced every 2 to $5 \mathrm{~km}$, with ramps dipping with angles up to 45 degrees.

To summarize, the ramps might be correlated to features on the top of the oceanic crust, such as R5, and create duplex structures forming the lower layer. In some cases, the roof of the duplex also acts as a pseudo-décollement leading to the formation of a large landward vergent thrust (T3, T5, T6, T8, T11, passive roof duplex, Bangs and Warburton, 1986). In other cases, pop-up structures seem to emerge at the front of the pseudo-décollement (T2, T4, T7, T9, T10, active roof duplex, Couzens-Schultz et al., 2003).

\subsection{Shortening and Timing}

Using the seismic data, we can estimate the shortening accumulated along this section of the wedge. To do so, we used the crude mass balance method of Hill et al. (2012) assuming no significant layer parallel shortening. We first define a flat surface corresponding to the supposed initial topography, assuming that there were no deformation at the beginning (Fig. 5). Then, we measure the surface of sediments above this flat surface and we assume that it is equal to the 
amount of sediments that have been transferred along the ramps. We consider that the displaced sediments have a rectangular shape.

The first unit (T1, T2, T3, fig. 5) has about $1.9 \mathrm{~km}^{2}$ of transferred sediments above the initial topography, accommodating a slip of $\sim 1 \mathrm{~km}$. By considering a constant frontal slip rate of $45 \mathrm{~mm} / \mathrm{yr}$, the deformation would have started about 22,200 years ago in this region. The fourth mixed vergent thrust system (T4) seems to have accommodated $0.5 \mathrm{~km}$ of slip and would have begun about 33,300 years ago, transferring $1.2 \mathrm{~km}^{2}$ of sediments. Then, the fifth thrust (T5) could have started 46,600 years ago and is the result of $0.6 \mathrm{~km}$ of slip transferring $1.7 \mathrm{~km}^{2}$ of sediments. The next unit (T6, T7, T8) seems to have accumulated a slip of about $5.3 \mathrm{~km}$, giving an amount of transferred sediment of the order of $17 \mathrm{~km}^{2}$. Its deformation is likely to have started 165,000 years ago. The resolution of the seismic reflection line is not good enough to estimate if $\mathrm{T} 6$ and $\mathrm{T} 7$ have been active at the same time. Then, the last unit of our section was probably formed about 300,000 years ago, accommodating $5.9 \mathrm{~km}$ of slip. This unit transferred $25.6 \mathrm{~km}^{2}$ of sediments.

The ratio of slip as well as the amount of transferred sediments between the unit 2 (T6, T7, T8) and 3 (T9, T10, T11) seem to be consistent. The frontal unit 1 has accommodated less slip. The total amount of shortening that we obtain in 300,000 years is $\sim 13.3 \mathrm{~km}$, suggesting that the accretionary prism is a recent structure.

\section{Mechanical Modeling}

\subsection{Limit Analysis Approach}


We now investigate the mechanical conditions that are required to activate a pseudodécollement and produce active or passive roof duplexes. In a passive roof duplex, the roof sequence is not displaced seaward but underthrust by the duplex (Banks and Warburton, 1986), leading to the formation of a landward thrust as T3, T5, T8 or T11. In an active roof duplex, the shortening is transferred seaward (Couzens-Schultz et al., 2003), a pop-up will then emerge at the front of the pseudo-décollement as T1-T2, T7, T9-T10. The aim of this study is to characterize the frictional parameters required to reproduce these observations. This will allow us to discuss the mode of deformation, either seismic or aseismic.

To do so, we rely on the limit analysis approach (Chandrasekharaiah and Debnath, 1994; Salençon, 2002), which is based on the principle of virtual powers and the theorem of maximum rock strength (Maillot and Leroy, 2006). In this study, the Coulomb criterion is used for the maximum rock strength. The principle of virtual power consists in studying the collapse mechanisms, in our study faults, by applying a virtual displacement over the structure. The method investigates all possible distribution of faults as a function of the mechanical properties and selects the optimal one leading to the least upper bound to the tectonic pushing force. This approach has previously been applied to retrieve frictional properties of accretionary wedge faults (Cubas et al., 2008; Souloumiac et al., 2009; Pons et al., 2013; Cubas et al., 2013a; 2013b) and has been validated quantitatively from comparison with analogue experiments (Cubas et al., 2013c). In this study, the simulations were run with the Optum-G2 software (OptumG2, 2013).

We assume a cohesionless wedge. To predict the location of active faults, we thus need to set-up the frictional parameters of the structure: the friction of the accretionary sediments or bulk $\left(\mu_{b u l k}=\tan \Phi_{b u l k}\right)$, the friction of the plate interface $\left(\mu_{P I}=\tan \Phi_{P I}\right)$, and the friction along pre- 
defined faults in the wedge, as the pseudo-décollement $\left(\mu_{\text {déco }}=\tan \Phi_{\text {déco }}\right)$ (Fig. 6a). Since the Optum-G2 software does not deal with over-pressure, we used effective frictions defined as:

$$
\mu_{e f f}=\mu(1-\lambda)
$$

with

$$
\tau=\mu(1-\lambda) \sigma_{\text {normal }}
$$

where $\tau$ and $\sigma_{\text {normal }}$ are the shear and normal stresses, $\mu$ is the friction coefficient, and $\lambda$ is the pore fluid pressure ratio as defined in Davis et al. (1983) for an accretionary wedge:

$\lambda=\frac{P+\rho_{\omega} g D}{\left|\sigma_{z}\right|+\rho_{\omega} g D}$

with $\rho$ and $\rho_{\omega}$ being the wedge material and water densities, $D$ is the water depth, $\sigma_{z}$ is the stress perpendicular to the décollement and $P$ is the pore pressure.

To understand the mechanical requirements for the formation of these structures, we first start with a basic geometry based on the seismic image. We use a $12 \mathrm{~km}$-long section representing the frontal part of the profile, formed by a triangular wedge followed by a $1 \mathrm{~km}$ thick flat layer corresponding to incoming and undeformed sediments (Fig. 6a). An intermediate décollement separated from the plate interface is added inside the accretionary wedge with a slope of $0^{\circ}$.

Since we do not know the pore pressure in the wedge, we start with assuming that the bulk (wedge) is in hydrostatic state and fix $\lambda_{B u l k}=0.4$. We also assume that the properties for the sedimentary layers are uniform. We use a standard friction for the bulk $\left(\mu_{B u l k}=0.57 ; \Phi_{B u l k}=30^{\circ}\right.$, Byerlee, 1978) resulting in an effective friction of $\mu_{\text {Bff }}^{\text {Bulk }}=0.34$ (eq.1). 


\subsection{Duplex and Pseudo-décollement}

We first investigate how to create a ramp that connects the plate interface with the pseudo-décollement (Fig. 6a). With the above geometry and the bulk friction, the maximum friction obtained from the modeling for allowing sliding along the plate interface is $\mu^{\text {eff }}$ Plback $_{\text {f }}=$ 0.23. Two conditions are required to create this ramp and to activate the pseudo-décollement. The first one is a pre-existing intermediate layer with a lower effective friction than that along the plate interface. For the selected geometry and bulk friction, we find $\mu_{\text {déco }}^{e f f}=0.16$. Since we chose the maximum possible friction along the plate interface and the minimum pore pressure ratio, the friction obtained along this intermediate décollement is an upper bound. The second condition for creating a ramp is either a geometrical or frictional change along the plate interface. A sudden increase of the effective friction $\left(\mu_{\text {Plback }}^{\text {eff }}<\mu_{\text {Pfront }}^{\text {eff }}\right)$ along the plate interface impedes the propagation along the plate interface (Fig. 6b). We observe the formation of a landward thrust at the kink between the décollement and the ramp, as well as a pop-up at the break of slope. Having a curved ramp, instead of a kink at the plate interface-ramp transition, would avoid the formation of a landward thrust. An irregular plate interface geometry would lead to the same result as the change of friction. We here show the effect of a seaward dipping normal fault cutting the plate interface (Fig. 6c).

The increase of effective friction could be due to a decrease of pore pressure related to a sudden change of sediments thickness. We could expect this change if the oceanic crust is segmented in horst and graben structures. The geometrical discontinuity could be related to the 
presence of a normal fault, a ridge or a seamount emerging from the oceanic crust as for ramp R5 in our interpretation.

\subsection{Pop-up structures}

We now investigate how to get passive or active roof duplexes. A passive roof duplex will lead to the formation of a landward thrust fault using the roof of the duplex as a décollement, whereas in the active roof duplex case, the intermediate décollement is activated and leads to the formation of a frontal pop-up. We thus add a fault representing the roof of the duplex in our model (Fig. 7a) and test different friction values along this fault $\left(\mu^{\text {eff }}{ }_{L T}\right)$ and the décollement $\left(\mu_{\text {eff }}^{\text {déco }}\right)$. The same friction is applied along the deeper part of the plate interface $\left(\mu_{\text {Plback }}^{e f f}=0.23\right)$. To create a ramp and use the intermediate décollement for the slip, we lock the frontal part of the plate interface by increasing its friction to the bulk friction $\left(\mu_{\text {PIFront }}^{\text {eff }}=\mu_{\text {Bulk }}^{\text {eff }}=\right.$ 0.34). To get enhanced slip along the landward thrust (Fig. 7b), it is necessary to lock the intermediate décollement $\left(\mu_{\text {eff }}^{\text {ef́co }} \geq 0.14\right)$. With lower friction $\left(0.035 \geq \mu^{\text {eff }}\right.$ déco $\left.\geq 0.12\right)$, the décollement is activated and a pop-up is formed at the break of slope (Fig. 7c). In that case, the landward thrust above the roof of the duplex is also activated although with little slip. Again, since we chose the maximum possible friction along the plate interface and the minimum pore pressure ratio, the friction obtained along the intermediate décollement has to be considered as an upper bound. Therefore, a low effective friction along the pseudo-décollement seems to be necessary to reproduce our observations.

\subsection{Frictional properties of the frontal section}


According to the seismic reflection image, the first three frontal pop-ups seem to be active. To assess if these pop-ups or the plate interface could be activated co-seismically during earthquakes or by aseismic slip, we can estimate their frictional properties (Cubas et al., 2013b). A high basal friction would mean that the fault slides aseismically (e.g. Rice et al., 2006), whereas a low effective friction could either be due to a long-term high pore pressure or to dynamic weakening during co-seismic slip. Here we study the $20 \mathrm{~km}$ long frontal part of the profile, using the real geometry for the bathymetry and the slab. Ramp (R1), the pseudodécollement (ID1) as well as three frontal pop-ups (T1, T2, T3) are added as pre-existent faults in the model set-up. We investigate four possible rupture to the toe scenarios:

1. The whole plate interface is activated.

2. The plate interface is activated up to the trench and the rupture cuts through the sediments (Fig. 8a).

3. The plate interface is activated up to the trench as well as the ramp and the frontal pop-ups.

4. The plate interface is activated up to the ramp, and the rupture steps up to the pseudodécollement activating the three frontal pop-ups (Fig. 8c).

Once again, we consider initial hydrostatic pore pressure in the wedge and we seek for the maximum effective friction on each fault for the four scenarios. The results, given in Table 1 are thus upper bounds. Results of scenario $\mathbf{2}$ and $\mathbf{4}$ are also shown in Fig. 8.

\begin{tabular}{|l|l|l|}
\hline Scenario & $\mu_{P I}$ & $\mu_{\text {fault, déco }}$ \\
\hline
\end{tabular}




\begin{tabular}{|l|l|l|}
\hline 1 & 0.1 & 0.34 \\
2 & 0.21 & 0.34 \\
3 & 0.21 & 0.17 \\
4 & 0.21 & 0.1 \\
\hline
\end{tabular}

Table 1. Effective friction values along the plate interface and along the pseudo-décollement and the frontal thrusts for the four different scenarios (with $\mu_{b u l k}=0.34$, bold values are for active faults.)

To activate the plate interface, an effective friction $\leq 0.21$ is required. To only activate the faults in the upper layer, the effective friction along the pseudo-décollement has to be $\leq 0.1$. A low effective friction is thus needed to activate the structures of the upper layer. The same study was applied along another CGGV line (CGGV line 20) located in the southern Mentawai segment where the 2010 tsunami earthquake occurred. Based on a structural analysis of this profile, Singh et al. (2011a) have argued that the rupture propagated to the surface, re-activating the frontal pop-up of the accretionary wedge. To activate the plate interface up to the toe, the effective friction along the plate interface has to be $\leq 0.15$, comparable to the value found with scenario $4(\leq 0.1)$. To activate the frontal pop-up, its effective friction has to be $\leq 0.08$, again comparable to the friction along the three frontal pop-ups in scenario $4(0.1)$.

\subsection{Frontal slip Assessment}

The limit analysis approach also provides virtual velocities of different blocks and discontinuities (i.e. faults). We can assume that the ratio between the virtual velocities of two blocks (after projection along their faults) is equal to the ratio of displacement between these two blocks (Cubas et al., 2013a; 2013b). This assumption allows estimating the ratio of slip 
accommodated by the plate interface and each fault. Since the convergence rate is $45 \mathrm{~mm} / \mathrm{yr}$ and the last great earthquake along this segment occurred in 1797, the slip deficit along the northern Mentawai segment would be of the order of $10 \mathrm{~m}$. If the frontal section is totally locked, and the frontal structures are only activated during earthquakes, we can expect $10 \mathrm{~m}$ of slip along the plate interface at the back of our model. We can estimate the amount of slip along the different faults for each scenario, which are given in Table 2.

\begin{tabular}{|c|c|c|c|c|c|c|c|c|c|c|}
\hline \multirow{2}{*}{ Scenario } & \multicolumn{2}{|c|}{ Backstop } & \multicolumn{2}{|c|}{ Frontal PI } & \multicolumn{2}{|l|}{ T1 } & \multicolumn{2}{|l|}{$\mathrm{T} 2$} & \multicolumn{2}{|l|}{ T3 } \\
\hline & $\delta_{x}(\mathrm{~m})$ & $\delta_{\mathrm{y}}(\mathrm{m})$ & $\delta_{x}(\mathrm{~m})$ & $\delta_{\mathrm{y}}(\mathrm{m})$ & $\delta_{\mathrm{x}}(\mathrm{m})$ & $\delta_{\mathrm{y}}(\mathrm{m})$ & $\delta_{\mathrm{x}}(\mathrm{m})$ & $\delta_{\mathrm{y}}(\mathrm{m})$ & $\delta_{\mathrm{x}}(\mathrm{m})$ & $\delta_{\mathrm{y}}(\mathrm{m})$ \\
\hline 1 & 10 & 0.5 & 9.6 & 1.2 & 10 & 2 & 10 & 2 & 10 & 2 \\
\hline 2 & 10 & 0.5 & 9. & 7.8 & 9.8 & 1.9 & 9.8 & 1.9 & 9.8 & 1.9 \\
\hline 3 & 10 & 0.5 & 3.2 & 2.1 & 9.5 & 5.6 & 9.5 & 4.5 & 9.7 & 2.7 \\
\hline 4 & 10 & 0.5 & 0 . & 0 . & 5.9 & 3.2 & 5.5 & 2. & 9.2 & 6.6 \\
\hline
\end{tabular}

Table 2. Expected horizontal $\left(\delta_{\mathrm{x}}\right)$ and vertical $\left(\delta_{\mathrm{y}}\right)$ slip for each scenario along the frontal plate interface (PI) and the three frontal pop-ups (T1, T2, T3) for a $10 \mathrm{~m}$ slip applied at the back of the structure (Back-wall).

For scenario 3 and 4, the rupture will propagate towards the trench and step up to the pseudodecollement activating upper thrusts. The tsunami would then be the result of the whole wedge displacement as well as the result of the uplift of the three frontal pop-ups. Notice that we systematically seek for the upper bounds on the effective frictions. Lower effective frictions 
would lead to larger slips. In addition, the limit analysis approach cannot take into account inertial and free surface effects. Our results are thus minimum values and larger values could be expected during an earthquake.

\section{Discussion}

The interpretation of seismic profile CGGV010 from the locked zone shows that the frontal section of the locked zone is active, similar to that along profile CGGV020 that ruptured up to the subudction front. This is confirmed by the presence of the first pop-up proximal to the trench (T1, fig. 3), although thrusts do not seem to have yet reached the surface, since they do not cut the topography. The three frontal pop-ups seem to have been active for the last 22,200 years and have accommodated about $1 \mathrm{~km}$ of slip. All the pop-ups are connected to a pseudo-décollement, which separates the wedge into two layers: a lower layer formed by duplexes, the roof of which serves as a pseudo-décollement for the mixed and landward vergent thrusts forming the upper layer (fig. 3b). Similar mixed to landward thrust structures have been observed in the 2004 earthquake rupture zone (Henstock et al., 2006; Fisher et al., 2007; Mosher et al., 2008; Dean et al., 2010; Gulick et al., 2011; Ghosal et al., 2014; Moeremans et al., 2014) and farther south in the 2010 earthquake rupture zone (Singh et al., 2011a), which led some authors to propose a correlation between landward vergence and tsunamigenic earthquake (Gulick et al., 2011; Moeremans et al., 2014). The presence of duplexes in the 2004 rupture zone has also been postulated by previous studies (Fisher et al., 2007; Gulick et al., 2011). As suggested for the 2004 event, the frontal thrust faults of the accretionary wedge could serve as pathway for the earthquake to reach the seafloor and enhance the associated tsunami (Henstock et al., 2006; Singh et al., 2008). 
Along the downgoing slab, some topographic features are found: an old normal fault, which now has been re-activated as a thrust, located near to the trench. Another feature is at $20 \mathrm{~km}$ from the trench, which might be an old normal fault or a ridge associated to the Investigator Ridge. It is hard to decipher whether the above deformation is due to this feature or not. A careful analysis of these structures suggests thrust faults responsible for these structures should originate in the oceanic crust, uplifting the basement. Similar thrust ramps have been observed in the 2004 earthquake rupture zone (Singh et al., 2008; 2012), suggesting the oceanic crust breaks as it subducts (Singh et al., 2008) at several places along the Sumatra margin.

From the mechanical modeling, we have shown that the formation of duplexes and the activation of the pseudo-décollement require either a sudden increase of effective friction along the plate interface or a geometrical discontinuity as well as a very low effective friction along the pseudodécollement. A low effective friction, $\mu_{\text {déco }}<0.1$, is also required to get the frontal pop-ups. If the pore pressure of the wedge is larger than hydrostatic, this maximal effective friction will decrease significantly. The increase of friction along the plate interface or the presence of a geometrical discontinuity could result from the subduction of an oceanic crust segmented by horst and graben structures, or successive seamounts, or zig-saw pattern created by thrusting of the oceanic crust (Singh et al., 2012). The low effective friction of the pseudo-décollement in the middle of the accretionary wedge could either be related to a high pore pressure interface or to dynamic weakening mechanisms.

In the high pore pressure over a long period case, the pore pressure ratio along the interface would be $\lambda=0.825$ (eq. 2), close to lithostatic. This very high pore pressure interface could be related to the transition from a low to highly compacted sediment transition. This could be produced by the presence a high-pressure fluid/gas layer above the plate interface. A high- 
amplitude reverse polarity (HARP) reflection (Dean et al., 2010) has been observed in the 2004 earthquake rupture zone. However, no HARP has been observed along our seismic reflection profile.

According to laboratory experiments and theoretical studies, values of friction strongly depend on the sliding velocity (e.g. Rice, 2006; Di Toro et al., 2011). The friction decreases at high slip rate due to dynamic weakening mechanisms such as thermal-pressurization (thermal pressurization increases the pore pressure along a fault and leads to a very low effective friction). In subduction zones, effective frictions lower than 0.1 have been found along megathrusts that were ruptured during earthquakes (Conin et al., 2012; Fulton et al., 2013; Cubas et al., 2013a; 2013b; Gao and Wang, 2014). For the Tohoku-Oki earthquake, estimates of dynamic effective frictions range between 0.003 and 0.08 (Conin et al., 2012; Kimura et al., 2012; Ujiie et al.; 2013; Cubas et al., 2013b) and 0.08 of apparent friction was proposed from the temperature anomaly (Fulton et al., 2013). On the contrary, aseismic accretionary wedges seem to be characterized by effective friction larger than 0.1 (Lallemand et al., 1994; Cubas et al., 2013a; 2013b). Since no HA-NP reflector is visible in our profile and the modeling of the seismic reflection profile located along the Southern Mentawai region where the 2010 tsunami earthquake occurred gave similar values of effective frictions, dynamic weakening seems a reasonable explanation for the activation of a pseudo-décollement and its associated pop-ups.

For the Tohoku-Oki earthquake, drilling results revealed that the earthquake propagated along a thin layer of smectite-rich clay up to the front (Chester et al., 2013). From temperature measurements and laboratory experiments, it has been shown that this layer was prone to thermal pressurization and characterized by a low dynamic friction (Fulton et al., 2013; Ujiie et al., 2013). As shown by Cubas et al. (2015), frontal rate-strengthening décollement with low 
permeability can occasionally weaken co-seismically by thermal pressurization, and accumulate very large seismic slips due to nearly complete stress drops. The pseudo-décollement of the Mentawai segment could also be due to a specific layer of clays, either characterized by a longterm high pore pressure or prone to thermal pressurization during earthquakes. In the second case, the rupture would propagate towards the toe, step up to the pseudo-décollement and propagate through the three most frontal pop-ups. The resulting tsunami would then be the result of the whole wedge displacement as well as the uplift of several meters along the three frontal pop-ups.

\section{Conclusion}

A high-resolution deep seismic profile allows us to characterize the nature of accretionary wedge near the subduction front in the Mentawai locked zone. We find that the upper part of the sedimentary wedge consists of pop-up structures with mixed and landward vergent thrusts and the lower part of-sub-horizontal reflections. A pseudo-décollement, most probably the roof of duplexes, seems to separate these two layers. From mechanical modeling, we show that two minimum conditions are required to activate the pseudo-décollement: a low effective friction along the pseudo-décollement $(\leq 0.1)$, and either a sudden increase of effective friction along the plate interface or an irregular geometry of the plate interface. We then model the frontal section of the seismic profile. We show that a low effective friction is required to activate the pseudodécollement and the three frontal pop-ups $(\leq 0.1)$. The low effective friction in the middle of the wedge could either be due to the presence of a long-term high pore pressure layer or to dynamic weakening associated with an earthquake. A similar layer was found by Singh et al. (2011a) in 
the 2010 tsunami earthquake region, south of our study area. If the deformation at the front of the wedge is indeed acquired during co-seismic slip, as $10 \mathrm{~m}$ of slip have been accumulated since the 1797 earthquake rupture, a large tsunami might be expected. From the modeling, we show that, in addition to the whole wedge displacement, if the frontal pop-ups are re-activated, the

minimum horizontal displacement and vertical uplift along those faults would range from 5.5 to $9.2 \mathrm{~m}$ and from 2 to $6.6 \mathrm{~m}$, respectively. Therefore, the risk of a large earthquake and subsequent tsunami in the locked zone is rather high.

\section{Acknowledgement}

Authors would like to acknowledge Indonesian Directorate General of Higher Education, Ministry National of Education and French Ministry for the fellowship. This work has been partially funded by the Agence Nationale de la Recherche (ANR, project ANR-13-PDOC-001301). We thank CGG for providing high-resolution deep seismic reflection data. The highresolution bathymetric data are courtesy of BPPT-BGR. We acknowledge H. Permana (LIPI) and Y. Djajadihardja (BPPT) for their support with the bathymetric data. We would like to thank also M. Chlieh for the permission to use the coupling model.

\section{References}

Ammon, C. J., Ji, C., Thio, H.-K., Robinson, D., Ni, S., Hjorleifsdottir, V., Kanamori, H., Lay, T., Das, S., Helmberger, D., Ichinose, G., Polet, J., Wald, D., 2005. Rupture process of the 2004 Sumatra-Andaman earthquake. Science, 308. doi: 10.1126/science.1112260. 
Banks, C.J., Warburton, J., 1986. 'Passive-roof' duplex geometry in the frontal structures of the Kirthar and Sulaiman mountain belts, Pakistan. Journal of Structural Geology 3, 229-238.

Bletery, Q., A. Sladen, B. Delouis, M. Vallée, J.-M. Nocquet, L. Rolland, and J. Jiang (2014), A detailed source model for the Mw 9.0 Tohoku-Oki earthquake reconciling geodesy, seismology, and tsunami records, J. Geophys. Res. Solid Earth, 119, doi:10.1002/2014JB011261.

Byerlee, J. D., 1978, Friction of rocks, Pure Appl. Geophys., 116, 615-626.

Byrne, D.E., Sykes, L.R. and Davis, D.M., 1992. Great thrust earthquakes and aseismic slip along the plate boundary of the Makran subduction zone. Journal of Geophysical Research 97: doi: 10.1029/91JB02165.

Chandrasekharaiah, D. S., Debnath, L., 1994. Continuum mechanics. Academic press, Inc.

Chester F., C. Rowe, K. Ujiie, J. Kirkpatrick, C. Regalla, J. Casey Moore, V. Toy, M. WolfsonSchwehr, S. Bose, J. Kameda, J. J. Mori, E. E. Brodsky, N. Eguchi, S. Toczko and Expedition 343 and 343T ScientistS, 2013. Structure and Composition of the PlateBoundary Slip Zone for the 2011 Tohoku-Oki Earthquake. Science, 342 (6163), p.12081211. doi:10.1126/science. 1243719 .

Chlieh, M., Avouac, J. P., Sieh, K., Natawidjaja, D. H. , Galetzka, J., 2008. Heterogeneous coupling of the Sumatran megathrust constrained by geodetic and paleogeodetic measurements. J. Geophys. Res., 113. doi: 10.1029/2007JB004981.

Conin, M., Henry, P., Godard, V., Bourlange, S., 2012. Splay fault slip in a subduction margin, a new model of evolution. Earth and Planet. Sci. Lett., 341-344. doi: 10.1016/j.eps1.2012.06.003. 
Couzens-Schultz, B. A., Vendeville, B. C., Wiltschko D. V., 2003. Duplex style and triangle zone formation: insights from physical modeling. Journal of Structural Geology, vol. 25, 1623-1644, doi:10.1016/S0191-8141(03)00004-X.

Cubas, N., Leroy, Y. M. , B. Maillot, 2008. Prediction of thrusting sequences in accretionary wedges. J. Geophys. Res., 113. doi: 0.1029/2008JB005717.

Cubas, N., Avouac, J. P., Souloumiac, P. , Leroy, Y., 2013a. Megathrust friction determined from mechanical analysis of the forearc in the Maule Earthquake area. Earth and Planetary Science Letters, 381. doi: 10.1016/j.eps1.2013.07.037.

Cubas, N., Avouac, J. P., Leroy, Y. M. , Pons, A., 2013b. Low friction along the high slip patch of the $2011 \mathrm{Mw} 9.0$ Tohoku-Oki earthquake required from the wedge structure and extensional splay faults. Geophysical Research Letters, 40. doi: 10.1002/grl.50682.

Cubas, N., Barnes, C. , Maillot, B., 2013c. Inverse method applied to a sand wedge: estimation of friction parameters and uncertainty analysis. Journal of Structural Geology, 55. doi: 10.1016/j.jsg.2013.07.003.

Cubas, N., Lapusta, N., Avouac, J.P., Perfettini, H. 2015. Numerical modeling of long-term earthquake sequences on the NE Japan megathrust: Comparison with observations and implications for fault friction, Earth and Planetary Science Letters, 419, http://dx.doi.org/10.1016/j.epsl.2015.03.002.

Davis, D.M., Suppe, J., Dahlen, F.A., 1983. Mechanics of fold-and-thrust belts and accretionary wedges. J. Geophys. Res., 88, 1153-1172.

Dean, S. M., L. C. McNeill, T. J. Henstock, J. M. Bull, S. P. S. Gulick, Ja. A. Austin, Jr., N. L. B. Bangs, Y.S. Djajadihardja, and H. Permana, 2010. Contrasting Décollement and Prism Properties over the Sumatra 2004-2005 Earthquake Rupture Boundary. Science, 329 
(5988), p.207-210. doi:10.1126/science.1189373.

Di Toro, G. D., Han, R., Hirose, T., Paola, N. D., Nielsen, S., Mizoguchi, K., Ferri, F., Cocco, M. , Shimamoto, T., 2011. Fault lubrication during earthquakes. Nature, 471. doi: 10.1038/nature09838.

Fisher, D., Mosher, D.C., Austin Jr., J.A., Gulick, S.P.S., Masterlark, T., Moran, K., 2007. Active deformation across the Sumatran forearc over the December 2004 Mw9.2 rupture. Geology 35, 99-102. doi:10.1130/G22993A.1.Fujiwara, T., Kodaira, S., No, T., Kaiho, Y., Takahashi, N., Kaneda, Y., 2011. The 2011 Tohoku-Oki earthquake: displacement reaching the trench axis. Science 334, 1240. http://dx.doi.org/10.1126/science.1211554.

Fulton, P. M., Brodsky, E. E., Kano, Y., Chester, J. J. M. F. M., Ishikawa, T., Harris, R. N., Lin, W., Egnuchi, N., Toczko, S., Expedition 343, T. , Sceintists, K.-., 2013. Low coseismic friction on the Tohoku-Oki Fault determined from temperature measurements. Science, 342. doi:10.1126/science.1243641.

Gao X. and K. Wang, 2014. Strength of stick-slip and creeping subduction megathrusts from heat flow observations, Science 345, 1038, DOI: 10.1126/science.1255487

Geist, E. L., Bilek, S. L., Arcas, D. , Titov, V. V., 2006. Differences in tsunami generation between the December 26, 2004 and March 28, 2005 Sumatra earthquakes. Earth Planets Space, 58. doi:10.1186/BF03353377

Ghosal, D., S. C. Singh and J. Martin, 2014. Shallow subsurface morphotectonics of the NW Sumatra subduction system using an integrated seismic imaging technique. Geophys. J. Int., 198, p.1818-1831. doi:10.1093/gii/ggu182.

Gulick, S.P.S., Austin Jr., J.A., McNeill, L.C., Bangs, N.L.B., Martin, K.M., Henstock, T.J., 
Bull, J.M., Dean, S., Djajadihardja, Y., Permana, H., 2011. Updip rupture of the 2004 Sumatra earthquake extended by thick indurated sediments. Nat. Geosci. 4, 453-456.

Henstock, T. J., McNeill, L. C. \& Tappin, D. R. 2006. Seafloor morphology of the Sumatran subduction zone: Surface rupture during megathrust earthquakes? Geology 34, 485-488.

Hill, E. M., Borrero, J. C., Huang, Z., Qiu, Q., Banerjee, P., Natawidjaja, D. H., Elosegui, P., Fritz, H. M., Suwargadi, B. W., Pranantyo, I. R., Li, L., Macpherson, K. A., Skanavis, V., Synolakis, C. E. , Sieh, K., 2012. The 2010 Mw 7.8 Mentawai Earthquake determined from tsunami field survey and near field GPS data. J. Geophys. Res., 117(B06402). doi:10.1029/2012JB009159.

Hsu, Y., Somins, M., Avouac, J. P., Galetzka, J., Sieh, K., Chlieh, M., Natawidjaja, D., Prawirodirdjo, L., Boch, Y., 2006. Frictional afterslip following the 2005 Nias Simeulue earthquake,Sumatra. Science, 312. doi:10.1126/science.1126960.

Ide, S., Baltay, A., Beroza, G., 2011. Shallow dynamic overshoot and energetic deep rupture in the $2011 \mathrm{Mw} 9.0$ Tohoku-oki earthquake. Science, 332. doi:10.1126/science.1207020.

Ishii, M., P. M. Shearer, H. Houston, and J. E. Vidale, 2007. Teleseismic P wave imaging of the 26 December 2004 Sumatra-Andaman and 28 March 2005 Sumatra earthquake ruptures using the Hi-net array, J. Geophys. Res., 112, B11307, doi:10.1029/2006JB004700.

Ito, Y., T. Tsuji, Y. Osada, M. Kido, D. Inazu, Y. Hayashi, H. Tsushima, R. Hino, and H. Fujimoto, 2011. Frontal wedge deformation near the source region of the 2011 TohokuOki earthquake, Geophys. Res. Lett., 38, L00G05, doi:10.1029/2011GL048355.

Kanamori, H., 1972. Mechanism of tsunami earthquakes. Physics of the Earth and Planetary Interiors, 6 . 
Kimura, G., Hina, S., Hamada, Y., Kameda, J., Tsuji, T., Kinoshita, M. , Yamaguchi, A., 2012. Runaway slip to the trench due to rupture of highly pressurized megathrust beneath the middle trench slope: The tsunamigenesis of the 2011 Tohoku earthquake off the east coast of northern Japan. Earth and Planet. Sci. Lett, 339-340. doi:10.1016/j.eps1.2012.04.002.

Kodaira, S. T. N., Nakamura, Y., Fujiwara, T., Kaiho, Y., Miura, S., Takahashi, N., Kaneda, Y., Taira, A., 2012. Coseismic fault rupture at the trench axis during the 2011 Tohoku-oki earthquake. Nature Geoscience, 5. doi: 10.1038/NGEO1547.

Konca, A. O., Avouac, J.-P., Sladen, A., Meltzner, A. J., Sieh, K., Fang, P., Li, Z., Galetzka, J., Genrich, J., Chlieh, M., Natawidjaja, D. H., Bock, Y., Fielding, E. J., Ji, C. , Helmberger, D. V., 2008. Partial rupture of locked patch of the Sumatra megathrust during the 2007 earthquake sequence. Nature, 456. doi:10.1038/nature07572.

Ladage, S., Weinrebe, W., Gaedicke, C., Barckhausen, U., Flueh, E. R., Heyde, I., Krabbenhoeft, A., Kopp, H., Fajar, S. , Djajadihardja, Y. S., 2006. Bathymetric survey images structure of Sumatra. EOS Transaction American Geophysical Union, 87. doi: 10.1029/2006EO170001.

Lallemand, S., Schnürle, P. , Malavieille, J., 1994. Coulomb theory applied to accretionary and non accretionary wedges: Possible causes for tectonic erosion and/or frontal accretion. J. of Geophys. Res., 99.

Lay, T., Kanamori, H., Ammon, C. J., Nettles, M., Ward, N. S., Aster, R. C., Beck, S. L., Bilek, S. L., Brudzinski, M. R., Bulter, R., DeShon, H. R., Ekstrom, G., Satake, K. , Sip-kin, S., 2004. The great Sumatra Andaman earthquake of 2004. Science, 308. doi: 10.1126/science.1112250. 
Lay, T., Ammon, C. J., Kanamori, H., Yamazaki, Y., K.F, Cheung, Hutko, A., 2011. The 25 October 2010 Mentawai tsunami earthquake (Mw 7.8) and the tsunami hazard presented by shallow megathrust ruptures. Geophysical Research Letters, 38. doi: 10.1029/2010GL046552.

Loveless, J. P., Meade, B. J., 2011. Spatial correlation of interseismic coupling and coseismic rupture Extent of the $2011 \mathrm{Mw} 9.0$ Tohoku-oki earthquake. Geophysical Research Letters, 8, L17306, doi:10.1029/2011GL048561.

Maillot, B., Leroy, Y., 2006. Kink-fold onset and development based on the maximum strength theorem. J. of the Mech. and Physics of Solids,54. doi:10.1016/j.jmps.2006.04.004.

Martin, K. M., S. P. S. Gulick, J. A. Austin Jr., K. Berglar, D. Franke, and Udrekh (2014), The West Andaman Fault: A complex strain-partitioning boundary at the seaward edge of the Aceh Basin, offshore Sumatra, Tectonics, 33, 786-806, doi:10.1002/2013TC003475.

McCaffrey, R., 1992. Oblique plate convergence, slipvectors, and forearc deformation. J. Geophys. Res., 97.

McClay, K. R., 1992, Glossary of thrust tectonics terms, in McClay, K. R., ed., Thrust tectonics: London, United Kingdom, Chapman \& Hall, p. 419-433.

Moeremans R., S. C. Singh, M. Mukti, J. McArdle, K. Johansen (2014), Seismic images of structural variations along the deformation front of the AndamanSumatra subduction zone: Implications for rupture propagation and tsunamigenesis, Earth Planet. Sci. Lett., 386, 7585, doi:10.1016/j.epsl.2013.11.003.

Mosher, D. C., Austin, J. A. Jr, Fisher, D. \& Gulick, S. P. Deformation of the northern Sumatra accretionary prism: Evidence for strain partitioning from high-resolution seismic reflection profiles and ROV observations. Mar. Geol. 252, 89-99 (2008). 
Mukti, M. M., Singh, S., Deighton, I., Hananto, N. D., Moeremans, R., Permana, H., 2012. Structural evolution of backthrusting in the Mentawai Fault Zone, onshore Sumatran forearc. Geochemistry Geophysics Geosystems, 13. doi: 10.1029/2012GC004199.

Natawidjaja, D. H., Sieh, K., Chlieh, M., Galetzka, J., Suwargadi, B.,Cheng, H. W., Edwards, R. L., Avouac, J. P. , Ward, S. N., 2006. Source parameters of the great Sumatran megathrust earthquakes of 1797 and 1833 inferred from coral microatolls. J. Geophys. Res., 111:B06403. doi:10.1029/2005JB004025.

Oleskevich, D. A., Hyndman, R. D. , Wang, K., 1999. The updip and downdip limits to great subduction earthquakes: thermal and structural models of Cascadia, south Alaska, SW Japan, and Chile. J. Geophys. Res., 104. doi: 10.1029/1999JB900060.

OptumG2. Optum computational engineering, 2013. URL http://www.optumce.com.

Ozawa, S., Nishimura, T., Suito, H., Kobayashi, T., Tobita, M. , Imakiire, T., 2011. Coseismic and postseismic slip of the 2011 magnitude 9 Tohoku-Oki earthquake. Nature, 117. doi: 10.1038 /nature10227.

Pons, A., Leroy, Y. M. , Lallemant, S., 2013. Fluid pressure control on splay fault activation in accretionary prism based on the maximum strength theorem with application to the Nankai wedge. J. of the Mech. and Physics of Solids, 368. doi: 10.1016/j.eps1.2013.02.038.

Prawirodirdjo, L., Bock, Y., Genrich, J. F., Puntodewo, S. S. O., Rais, J., Subarya, C. , Sutisna, S., 2000. One century of tectonic deformation along the Sumatran fault from triangulation and Global Postioning System surveys. J. Geophys. Res., 105. doi: 10.1029/2000JB900150.

Rice, J. R., 2006. Heating and weakening of faults during earthquake slip. J. Geophys. Res., 111. doi: 10.1029/2005JB004006. 
Salençon, J., 2002. De l'elasto-plasticit_e au calcul a_la rupture. J. of the Mech. and Physics of Solids, Ellipses, 264p.

Scholz, C. H., 1998, Earthquakes and friction laws, Nature, 391, 37-42, doi:10.1038/34097.

Sieh, K., Natawidjaja, D. H., Meltzner, A. J., Shen, C.-C., Cheng, H., Li, K.-S., Suwargadi, B. W., Galetzka, J., Philibosian, B. , Edwards, R. L., (2008). Earthquake supercycles inferred from sea-level changes recorded in the corals of west sumatra. Science, 322. doi: 10.1126/science.1163589.

Singh, S. C., Hobbs, W. , Snyder, D. B., 1996. Broadband receiver response from dual-streamer data and applications in deep reflection seismology. Geophysics, 232-243. doi: $10.1190 / 1.1443944$.

Singh, S. C., Carton, H., Tapponnier, P., Hananto, N. D., Chauhan, A. P. S., Hartoyo, D., Bayly, M., Moeljopranoto, S., Bunting, T., Christie, P., Lubis, H. , Martin, J., 2008. Seismic evidence for broken oceanic crust in the 2004 Sumatra earthquake epicentral region. Nature Geoscience,1. doi: 10.1038/ngeo336.

Singh, S. C., Hananto, N., Mukti, M., Permana, H., Djajadihardja, Y., Harjono, H., 2011 a. Seismic images of the megathrust rupture during the 25th October 2010 Pagai earthquake, SW Sumatra: Frontal rupture and large tsunami. Geophysical Research Letters, 38. doi:10.1029/2011GL048935.

Singh, S. C., Hananto, N. D. , Chauhan, A. P. S., 2011b. Enhanced reflectivity of backthrusts in the recent great sumatran earthquake rupture zones. Geophysical Research Letters, 38. doi: 10.1029/2010GL046227. 
Singh, S. C., Moeremans, R., McArdle, J., Johansen, K. 2013. Seismic images of the sliver strike-slip fault and back thrust in the Andaman-Nicobar region, Journal of Geophysical Research Atmospheres 10/2013; 118(10):5208-5224. DOI:10.1002/jgrb.50378.

Souloumiac, P., Leroy, Y. M., Maillot, B. , Krabbenhoft, K., 2009. Predicting stress distributions in fold-and-thrust belts and accretionary wedges by optimization. J. Geophys. Res., 114. doi:10.1029/2008JB005986.

Tilmann F. J., Craig T. J., Grevemeyer I., Suwargadi B., Kopp H. and E. Flueh, 2010. The updip seismic/aseismic transition of the Sumatra megathrust illuminated by aftershocks of the 2004 Aceh-Andaman and 2005 Nias events, Geophys. J. Int., doi: 10.1111/j.1365246X.2010.04597.x

Ujiie, K., Tanaka, H., Saito, T., Tsutsumi, A., Mori, J. J., Kameda, J., Brodsky, E. E., Chester, F. M., Eguchi, N., S.Toczko, 343, E., Scientists, T., 2013. Low coseismic shear stress on the tohoku-oki megathrust determined from laboratory experiments. Science, 342. doi: 10.1126/science. 1243485 .

Wei, S., Graves, 618 R., Helmberger, D., Avouac, J. P., Jiang, J., 2012. Sources of shaking and ooding during the Tohoku-Oki earthquake: A mixture of rupture styles. Earth and Planet. Sci. Lett., 333-334. doi:10.1016/j.eps1.2012.04.006. 


\section{Captions}

Figure 1

a. Geodynamic setting and last major earthquakes of the Sumatra subduction zone (epicenters from USGS combined with GCMT focal mechanisms, high resolution bathymetry from GEBCO and a compilation of German data set (Ladage et al., 2006) recorded during the SeaCause cruises (Mukti et al., 2010). The CGGV10 deep seismic reflection profile acquired by CGGVeritas in 2009 in the northern Mentawai gap is shown in black.

b. Slip deficit from Chlieh et al. (2008) and Konca et al. (2008). We can observe two highly coupled zones: one below Nias island, another along the Mentawai islands. Purple and green boxes show the 1833 and 1797 historical ruptures of the Mentawai segment (Chlieh et al., 2008).

Pink box shows location of figure 2 profile.

Figure 2

a. CGGV 10 non-interpreted seismic reflection profile from CGGVeritas (VE 1:1).

b. Interval velocity profile smoothed by robust local regression obtained from the RMS velocity data using dix equation.

c. Combination of the seismic reflection profile with the interval velocity. We can observe a higher velocity along the down-going plate as well as two layers within the wedge, that could be due to the transition from low to highly compacted sediments. 
Figure 3

a. Non-interpreted seismic reflection profile (VE 1:1).

b. Structural interpretation. The accretionary wedge is composed of two layers as highlighted by the velocity model (fig.2b). The shallow layer is formed by pop-ups rooting on a pseudodécollement, connected to the plate interface through ramps. The duplexes form the deeper layer, and the roof of these duplexes acts as a pseudo-décollement. T: Thrust system, R: Ramp, PD: Pseudo-Décollement, T: Backthrust, NF: Normal Fault.

Figure 4

a. Non-interpreted and b. interpreted seismic reflection profile showing pop-ups rooting on the roof of a duplex (VE 1:2).

Figure 5

Shortening and timing of the deformation obtained from the mass balance formula of Hill (2012). A rectangular surface (dashed surface) was used to calculate the equivalent amount of transferred sediments above a supposed initially flat topography (grey surface). The total shortening for the whole section is about $13.3 \mathrm{~km}$ for the past 300,000 years. 


\section{Figure 6}

a. Model set-up to study how to link the plate interface to the intermediate décollement. Internal accretionary wedge friction $\mu_{B u l k}=0.34$, topographic slope $\alpha=5.7^{\circ}$, plate interface $\operatorname{dip} \beta=5^{\circ}$.

b. Intermediate décollement with low effective friction $\left(\mu_{\text {Déco }}=0.16\right)$ and increase of friction along the plate interface $\left(\mu_{\text {PIback }}=0.23, \mu_{\text {PIfront }}=0.34\right)$. The normalized virtual vertical velocity field shows the relative motion between the blocks in the vertical direction.

c. Intermediate décollement with low effective friction $\left(\mu_{D e ́ c o}=0.12\right)$ and irregular geometry along the plate interface corresponding to a seaward dipping normal fault cutting the plate interface.

Figure 7

a. Model setup to study how to get passive or active roof duplex. Internal accretionary wedge friction $\mu_{B u l k}=0.34$, topographic slope $\alpha=5.7^{\circ}$, plate interface $\operatorname{dip} \beta=5^{\circ}$.

b. Enhanced slip along the landward thrust for effective friction along the intermediate décollement $\mu_{\text {Déco }} \geq 0.14\left(\mu_{L T}=0.12\right)$. The normalized virtual vertical velocity field shows the relative motion between the blocks in the vertical direction.

c. Intermediate décollement fully activated and formation of a pop-up strcuture at the slope break for $\mu_{\text {Déco }} \leq 0.12\left(\mu_{B T}=0.12\right)$. Less slip is accommodated along the landward thrust. 


\section{Figure 8}

a. Normalized vertical virtual velocity field and b. minimal amount of slip expected for the scenario 2 (plate interface activated up to the trench).

c. Normalized vertical virtual velocity field and d. minimal amount of slip expected for the scenario 4 (the three frontal pop-ups are activated). 

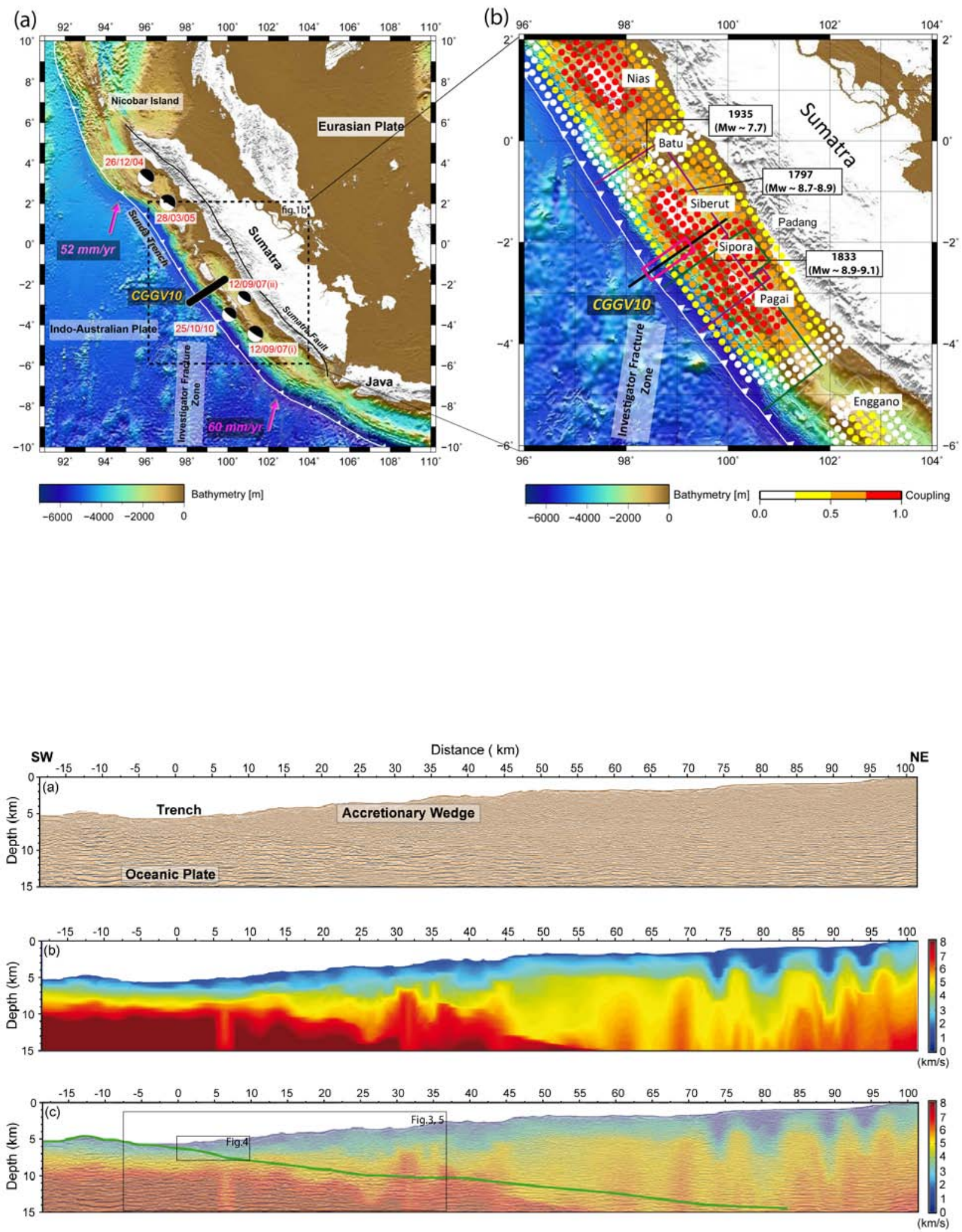

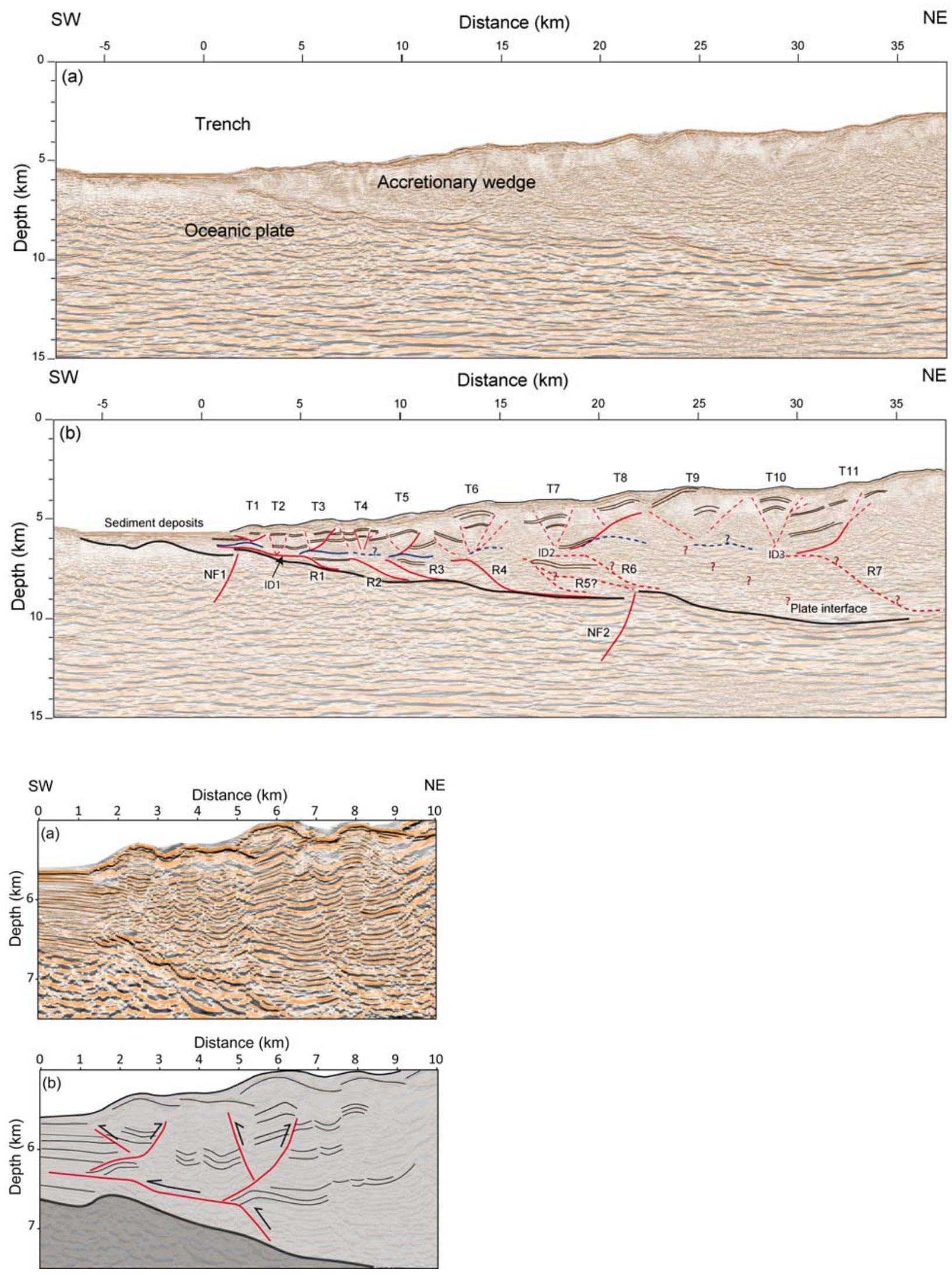


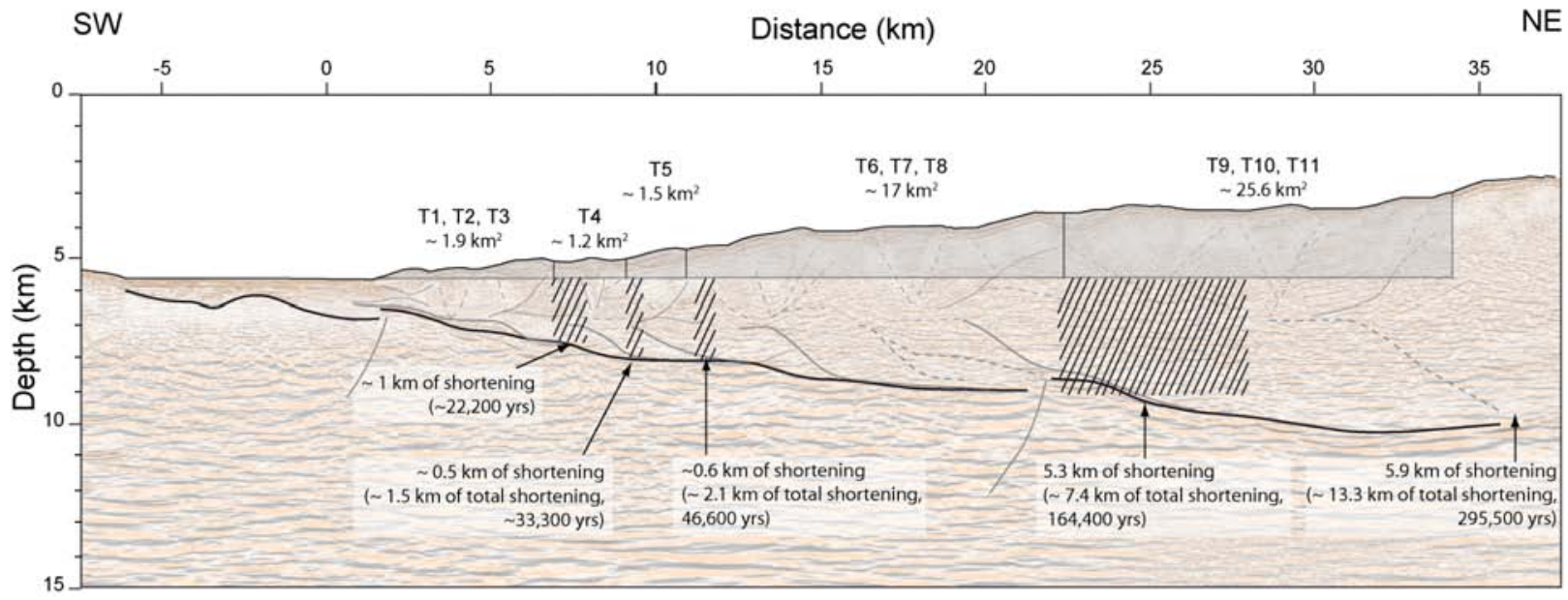

(a)

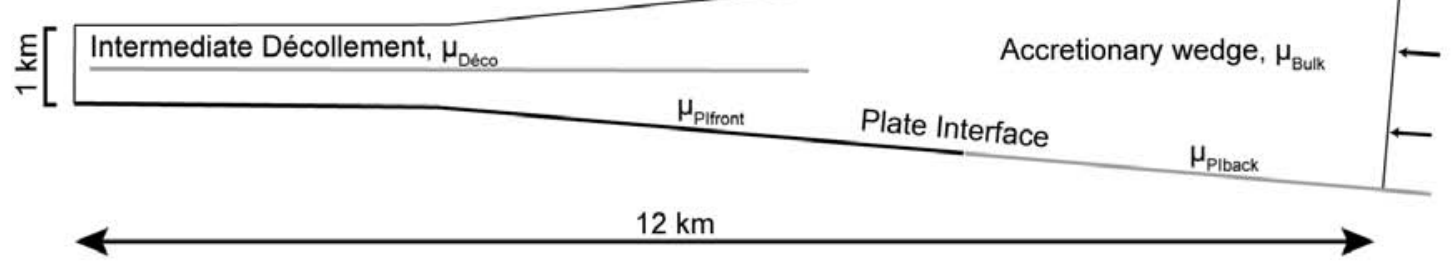

(b)

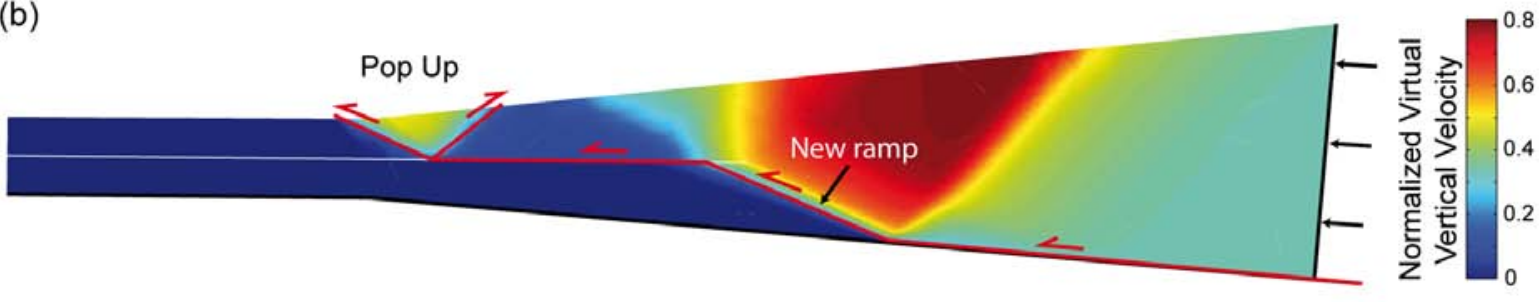

(c)

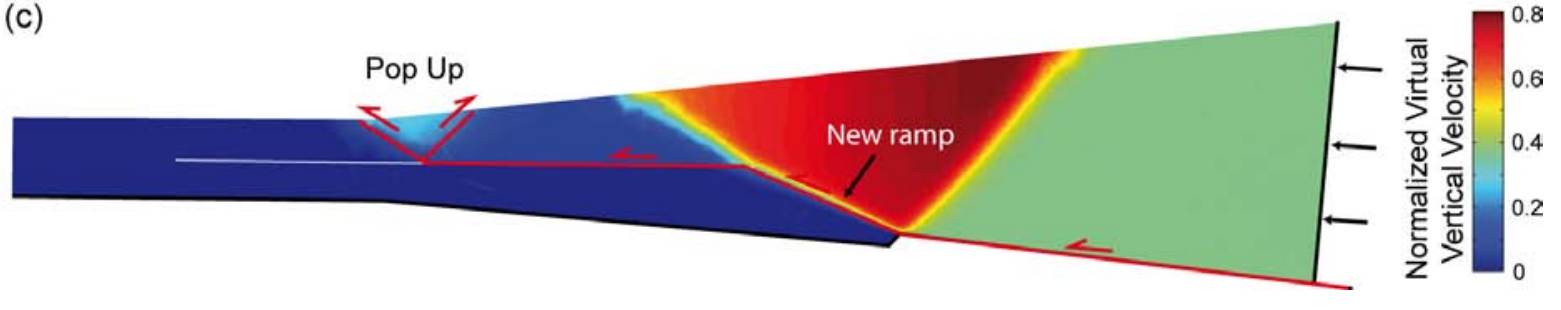



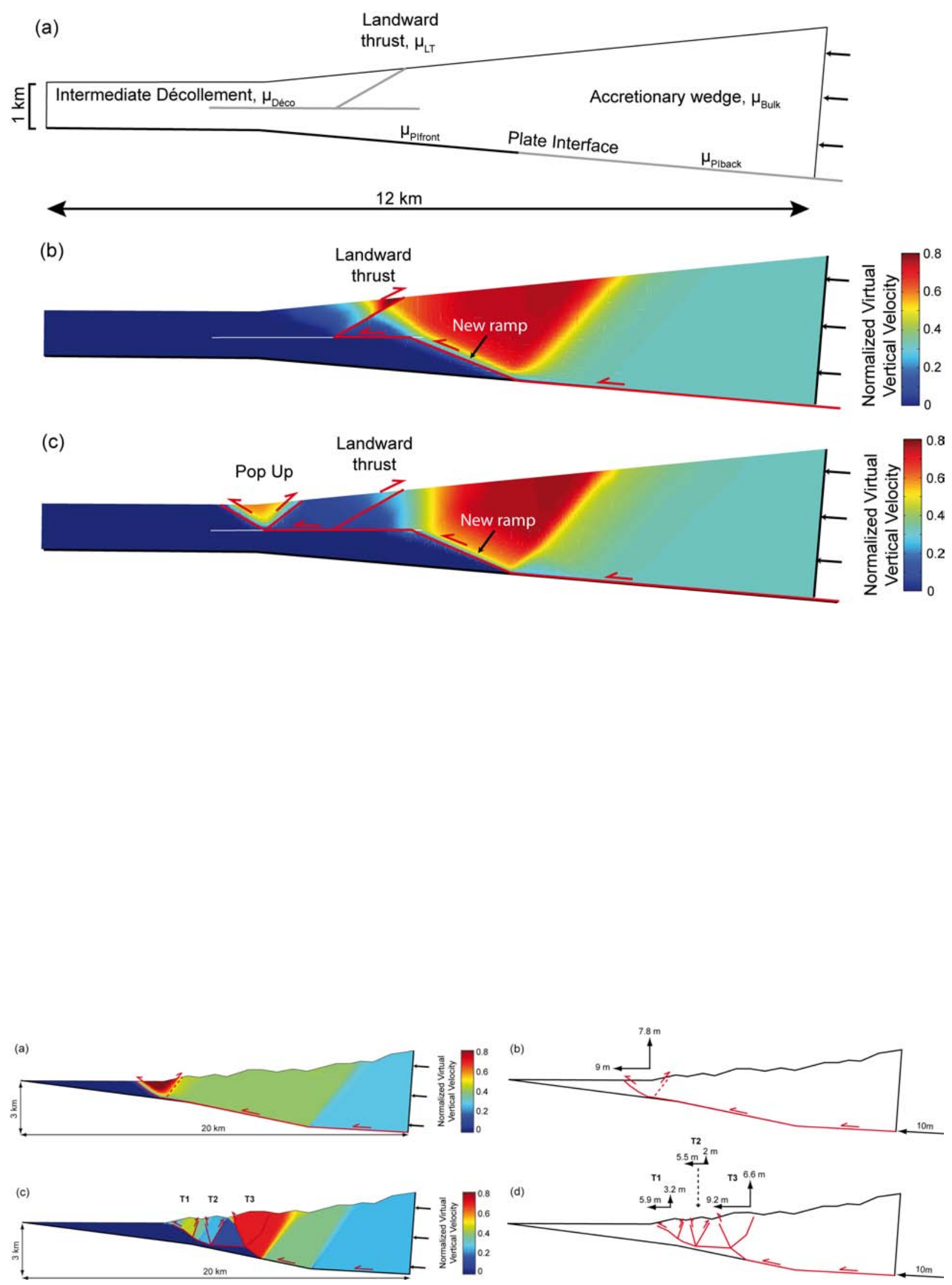